\title{
Analisis Kesulitan Siswa Dalam Menyelesaikan Soal Sistem Persamaan Linear Dua Variabel Pada Kelas VIII
}

\author{
Florensia Kolo ${ }^{1 *}$, Selestina Nahak $^{2}$ Fitriani $^{3}$ \\ ${ }^{1,2,3}$ Universitas Timor, \\ fkolo2411@gmail.com
}

\begin{abstract}
Informasi Artikel Abstrak
Revisi:

09 Desember 2021

Diterima:

14 Desember 2021

Diterbitkan:

30 Desember 2021

\section{Kata Kunci}

Analisis

Kesulitan

Sistem persamaan linear

dua variabel

Tujuan dari penelitian ini adalah untuk mengetahui kesulitan yang dialami siswa dalam menyelesaikan soal sistem persamaan linear dua variabel dan untuk mengetahui faktor - faktor yang menyebabkan siswa kesulitan dalam menyelesaikan soal sistem persamaan linear dua variabel pada kelas VIII SMP Negeri Satap Amol. Metode penelitian yang digunakan adalah deskriptif kualitatif. Subjek penelitian ini adalah siswa kelas VIII A SMP Negeri Satap Amol yang berjumlah 3 orang. Teknik pengumpulan data yang digunakan adalah tes dan wawancara. Instrumen dalam penelitian ini adalah peneliti, soal tes, pedoman wawancara dan dokumentasi. Teknik analisis data dalam penelitian ini adalah mereduksi data, pemaparan data dan menarik kesimpulan. Berdasarkan hasil penelitian, kesulitan yang dialami siswa yaitu kesulitan konsep, kesulitan prinsip dan kesulitan menyelesaikan masalah verbal. Faktor - faktor yang menyebabkan siswa mengalami kesulitan yaitu siswa buru - buru dalam mengerjakan soal, siswa malu bertanya, catatan siswa kurang lengkap, siswa tidak belajar, siswa mengalami kekeliruan dalam mengerjakan soal,siswa tidak memahami dan mengerti, siswa kurang teliti dalam mengerjakan soal,siswa tidak membaca yang diperintahkan pada soal, siswa tidak tau apa yang diketahui dan ditanyakan pada soal.
\end{abstract}

\begin{abstract}
The porpuse of this study was to find out the difficulties faced by students in solving two-variable system of linear equations and to find out the factors that caused students difficulties in solving two-variable system of linear equations in class VIII A SMP Negeri Satap Amol which amounted to 3 people. The research method used is descriptive qualitative. Data collection techniques used are tests and interviews. The instruments in this study were researchers, test questions, interview guidelines and documentation. The data analysis technique in this research is to reduce data, present data and conclusions. Based on the results of the study, the difficulties experienced by students were conceptual difficulties, principle' difficulties and difficulties in solving verbal problems. The factors that cause students to have difficulty are students rushing in working on questions, student are embarrassed to ask, students records are incomplete, student do not study, student experience errors in working on questions, students not understanding, studentsare less thorough in working on questions, students do not read the instruction on the questions, students do not know what is known and asked jn the questions.
\end{abstract}

Kolo, F, Nahak, Selestina. \& Fitriani. (2021). Analisis Kesulitan Siswa Dalam Menyelesaikan Soal Sistem Persamaan Linear Dua Variabel Pada Kelas VIII. Math-Edu: Jurnal Ilmu Pendidikan Matematika, vol (no), pp-pp. Doi: https://doi.org/10.32938/jipm.6.3.2021.100-114 


\section{Pendahuluan}

Matematika merupakan salah satu ilmu pengetahuan yang sangat penting untuk dipelajari di setiap jenjang pendidikan mulai dari tingkat Sekolah Dasar (SD), Sekolah Menengah Pertama (SMP), Sekolah Menengah Atas (SMA), sampai Perguruan Tinggi (PT). Hal ini dikarenakan matematika sangat dibutuhkan untuk memecahkan berbagai persoalan kehidupan dalam bidang ekonomi dan lain sebagainya.

Di sekolah, matematika merupakan salah satu mata pelajaran dari sekian banyak pelajaran yang diajarkan secara baik dan ilmiah seperti mata pelajaran lainnya. Menurut pengamatan dan pengalaman, Dienes dalam Ruseffendi (2006:156) mengatakan bahwa terdapat anak-anak yang menyenangi matematika hanya pada permulaan mereka berkenalan dengan matematika yang sederhana. Semakin tinggi jenjang sekolahnya semakin sukar materi yang dipelajarinya menyebabkan semakin kurang minat dalam mempelajarinya. Disamping itu terdapat banyak anak-anak yang setelah belajar matematika bagian sederhana pun tidak mampu dipahaminya, banyak konsep yang dipahaminya secara keliru. Matematika dianggap sebagai ilmu yang sukar, ruwet dan sulit dipahami. Dengan demikian secara universal matematika masih dipandang sebagai mata pelajaran yang sulit dan menakutkan siswa.

Salah satu materi dalam matematika yang dipelajari oleh siswa kelas VIII Sekolah Menengah Pertama adalah sistem persamaan linear dua variabel. Materi sistem persamaan linear dua variabel memiliki tingkat kesulitan yang cukup tinggi sehingga banyak siswa yang mengalami kesulitan dalam menyelesaikan soal. Hasil penelitian Idris, dkk (2016) mengatakan bahwa terdapat 3 jenis kesulitan yang dialami siswa dalam menyelesaikan soal sistem persamaan linear dua variabel yaitu pertama kesulitan fakta, yaitu kesulitan dalam menempatkan lambang-lambang yang membentuk persamaan linear dua variabel, kedua kesulitan konsep, yaitu kesulitan dalam merumuskan model matematika yang berkaitan dengan sistem persamaan linear dua variabel, ketiga kesulitan prinsip, yaitu dalam menggunakan sifat penambahan dan perkalian pada persamaan serta kesulitan dalam menggunakan metode dalam menentukan solusi dari sistem persamaan linear dua variabel, keempat kesulitan skill, yaitu dalam melakukan operasi pada bilangan. Arga Arafan, dkk (2018) mengatakan bahwa kesulitan yang dialami siswa dalam menyelesaikan soal sistem persamaan linear dua variabel ada 3 yaitu (1) kesulitan memahami simbol, (2) kesulitan proses, (3) kesulitan perhitungan. Sasmita (2019) mengatakan bahwa kesulitan yang dialami siswa dalam menyelesaikan soal sistem persamaan linear dua variabel yaitu pertama kesulitan konsep, terletak pada kesalahan siswa dalam memberikan alasan apakah itu termasuk sistem persamaan linear dua variabel atau bukan, tidak dapat menentukan variabel pada suatu sistem persamaan linear dua variabel, kesalahan dalam menuliskan himpunan penyelesaian dan siswa tidak memahami pengertian metode gabungan dalam penyelesaian sistem persamaan linear dua variabel. Kedua kesulitan prinsip, terletak pada kesalahan dalam mengubah kedalam bentuk baku, kesalahan dalam mengubah suatu persamaan dan kesalahan dalam 
menggunakan rumus pada umumnya dalam penyelesaian metode gabungan. Ketiga kesulitan keterampilan, terletak pada kesalahan dalam menuliskan bentuk baku, kesalahan serta kesulitan dalam mengoperasikan bilangan dan kesalahan siswa dalam menuliskan soal pada saat menyelesaikan jawaban.

Berdasarkan hasil wawancara penulis dengan guru matematika kelas VIII SMP Negeri Satap Amol, hasil belajar siswa pada materi sistem persamaan linear menunjukkan bahwa 50\% siswa belum mencapai kriteria ketuntasan minimal (KKM) yang telah ditentukan yaitu 75. Hal ini yang membuat penulis berpendapat bahwa banyak siswa masih mengalami kesulitan dalam menyelesaikan soal pada materi sistem persamaan linear dua variabel sehingga belum dapat mencapai hasil yang diharapkan.

Tujuan dari penelitian ini adalah untuk mengetahui kesulitan yang dilakukan siswa dalam menyelesaikan soal sistem persamaan linear dua variabel dan untuk mengetahui faktor - faktor yang menyebabkan siswa kesulitan dalam menyelesaikan soal sistem persamaan linear dua variabel. Untuk mencapai tujuan dari penelitian ini terdapat beberapa kajian yang digunakan yaitu:

\section{A. Analisis Kesulitan Siswa}

Menurut kamus besar bahasa Indonesia (2020) analisis adalah penyelidikan terhadap suatu peristiwa (karangan, perbuatan, dan sebagainya) untuk mengetahui keadaan yang sebenarnya (sebab musababnya, duduk perkaranya dan sebagainya), penguraian suatu pokok atas berbagai bagianbagiannya dan penelaahan bagian itu sendiri serta hubungan antar bagian untuk memperoleh pengertian yang tepat dan pemahaman arti keseluruhan). Sedangkan menurut Sudjana (2014: 27) analisis adalah usaha memilah suatu integritas menjadi unsur-unsur atau bagian-bagian sehingga jelas hirearkinya dan atau susunan. Analisis menurut Sudijono (2009: 51) adalah kemampuan seseorang untuk merinci atau menguraikan suatu bahan atau objek menurut bagian-bagian yang lebih kecil dan memahami hubungan bagian yang satu dan yang lain. Analisis merupakan kegiatan penguraian suatu pokok atas berbagai bagiannya dan penelaahan bagian itu sendiri serta hubungan antar bagian guna memperoleh pengertian yang tepat dan pemahaman arti keseluruhan. Atau dengan kata lain bahwa analisis adalah suatu usaha untuk mengamati secara detail tentang suatu hal atau benda dengan cara menguraikan komponen - komponen pembentuknya atau penyusunnya untuk dikaji lebih lanjut. Dengan demikian dapat disimpulkan bahwa analisis adalah usaha penyelidikan terhadap suatu objek atau suatu peristiwa atas bagian-bagian serta hubungan antar tiap bagiannya agar diketahui keadaan yang sebenarnya.

Kesulitan merupakan ketidakmampuan seseorang dalam menyelesaikan suatu masalah sehingga seseorang akan merasa berat dan sulit ketika dihadapkan pada suatu masalah baik masalah pribadi maupun umum. Kesulitan menurut Kamus Besar Bahasa Indonesia adalah segala sesuatu yang membuat tidak lancar (lambat). Kesulitan dalam bentuk apapun akan menghalangi seseorang untuk dapat mencapai tujuan. Kesulitan merupakan faktor yang dapat menjadikan seseorang itu menjadi lambat atau berhenti sama sekali dalam mencapai tujuannya, salah satu contohnya adalah kesulitan 
belajar. Kesulitan belajar merupakan kumpulan gangguan yang bervariasi manifestasinya, berupa kesulitan dalam memperoleh dan menggunakan kemampuan mendengar, berbicara, membaca, berpikir dan berhitung (Febrini, 2017: 161). Menurut Subini (2012: 57-58) kesulitan belajar merupakan suatu kondisi dimana kompotensi atau prestasi yang dicapai tidak sesuai dengan kriteria standar yang telah ditetapkan, baik berbentuk sikap, pengetahuan maupun keterampilan. Proses belajar mengajar ditandai dengan adanya hambatan untuk mencapai hasil belajar yang lebih baik. Menurut Thursan Hakim (2005: 14) kesulitan belajar adalah suatu kondisi yang menimbulkan hambatan dalam proses belajar seseorang.

Kesulitan belajar ini merupakan kumpulan dari gangguan yang heterogen yang timbul bisa berupa gangguan bahasa lisan, bahasa baca, bahasa tulis, juga terhitung. Pada saat praktik sering dijumpai kesulitan belajar pada bidang yang satu bisa juga berhubungan dengan bidang lainya. Setiap manusia memiliki kesulitan dalam belajar masing-masing, ada yang kesulitan belajar matematika, ada juga yang Kimia, ada yang Fisika dan lain sebagainya. Sementara itu menurut Abdurrahman (2012: 213) kesulitan dalam belajar dibagi menjadi dua yaitu kesulitan belajar yang berhubungan dengan perkembangan (mencakup gangguan motorik, kesulitan komunikasi, dan kesulitan dalam penyesuaian dalam perilaku sosial), dan yang kedua yaitu kesulitan belajar dalam akademik (mencakup penguasaan keterampilan dalam membaca, menulis, dan pemahaman matematika).

Supaya membantu siswa dalam menyelesaikan masalah yang dihadapi, siswa perlu mengenali kesulitan dan kesalahan yang dihadapi oleh siswa, sehingga akan menemukan solusi yang tepat untuk masalah tersebut. Sedangkan Koesteor (2012: 107) menjelaskan bahwa kesulitan belajar dapat diartikan sebagai suatu kegagalan yang dialami oleh siswa dalam mengikuti program pembelajaran di sekolahnya. Siswa tidak mampu memenuhi harapan yang tercantum sebagai tujuan formal dari kurikulum maupun yang ada dalam pandangan atau anggapan guru maupun kepala sekolah. Dari uraian definisi kesulitan belajar di atas maka dapat disimpulkan bahwa kesulitan merupakan keadaan dimana siswa tidak mampu atau kurang mampu menyelesaikan suatu permasalahan seperti soal-soal secara mandiri. Dari pengertian di atas juga dapat ditarik kesimpulan bahwa adanya hambatan dalam kegiatan belajar mengajar yang kemudian menjadikan kegiatan belajar tersebut tidak tercapai tujuannya atau prestasi belajar siswa menjadi rendah.

Berdasarkan definisi analisis dan kesulitan di atas maka dapat disimpulkan bahwa analisis kesulitan adalah penguraian secara detail terhadap suatu objek atau suatu peristiwa yang menghambat seseorang dalam mencapai proses belajarnya. Hambatan tersebut membuat seseorang menunjukkan hasil belajar yang rendah dibawah rata- rata nilai yang dicapai atau dibawah potensi yang dimiliki dan prestasi belajar siswa menjadi rendah.

\section{B. Jenis - Jenis Kesulitan Siswa Dalam Menyelesaikan Soal}

Dalam menentukan jenis kesulitan siswa dapat dilakukan dengan menganalisis kesulitan siswa dalam mengerjakan soal. Menurut Wigati, T. U. (2012: 5 ) jenis-jenis kesulitan belajar matematika meliputi 
1) kesulitan penggunaan konsep, indikator kesulitan penggunaan konsep adalah siswa mampu menandai, mengungkapkan dengan kata - kata dan mengidentifikasi konsep serta mengungkapkan model, 2) kesulitan penggunaan prinsip, indikator penggunaan prinsip adalah siswa mampu memberikan alasan pada langkah - langkah penggunaan prinsip menggeneralisasi prinsip yang benar dan memodifikasi suatu prinsip, 3) kesulitan dalam mengungkapkan informasi dan kesulitan berhitung. Menurut Cooney dalam Abdurrahman (2003: 287) kesulitan dikategorikan dalam 3 jenis yaitu: kesulitan dalam mempelajari konsep (kesulitan dalam satu materi), kesulitan dalam menerapkan prinsip (kesulitan dalam menerapkan konsep artinya kesulitan dalam mengaitkan konsep antar materi), kesulitan dalam menyelesaikan masalah verbal (kesulitan dalam menyelesaikan soal-soal yang berhubungan dengan masalah verbal atau soal cerita). Dalam penelitian ini, difokuskan pada kesulitan siswa dalam mempelajari konsep, kesulitan dalam menerapkan prinsip dan kesulitan dalam menyelesaikan masalah verbal yang dirujuk pada pendapatnya Abdurahman (2003: 287).

\section{Faktor-Faktor Penyebab Siswa Kesulitan Dalam Menyelesaikan Soal}

Faktor - faktor penyebab siswa kesulitan belajar adalah faktor internal (faktor dari dalam diri siswa) yakni keadaan jasmani dan psikologi siswa dan faktor eksternal (faktor dari luar siswa) yakni kondisi lingkungan disekitar siswa. Amir dan Risnawati (2016), menjelaskan faktor internal dan eksternal sebagai berikut:

1. Faktor internal siswa

a. Ciri khas atau karakter siswa

Persoalan internal pembelajaran berkaitan dengan kondisi kepribadian siswa baik fisik maupun mental siswa.

b. Sikap terhadap belajar

Sikap merupakan kemampuan memberikan penilaian tentang sesuatu yang membawa diri sesuai dengan penilaian.

c. Motivasi belajar

Motivasi juga sangat menentukan keberhasilan belajar. Motivasi mendorong siswa untuk mengerjakan sesuatu.

d. Konsentrasi belajar

Konsentrasi belajar merupakan kemampuan memusatkan perhatian pada pembelajaran. Pemusatan perhatian tersebut tertuju pada isi bahan belajar maupun proses memperolehnya.

e. Rasa percaya diri siswa

Rasa percaya diri timbul dari keinginan mewujudkan diri bertindak dan berhasil. Dari segi perkembangan, rasa percaya diri dapat timbul berkat adanya pengakuan dari lngkungan.

f. Intelegensi dan keberhasilan belajar 
Intelegensi dianggap sebagai suatu norma umum dalam keberhasilan belajar

g. Kebiasaan belajar

Dalam kehidupan sehari-hari ditemukan adanya kebiasaan belajar yang kurang baik. Kebiasaan tersebut antara lain berupa belajar pada akhir semester, belajar tidak teratur dan menyia-nyiakan kesempatan belajar.

2. Faktor eksternal siswa

a. Lingkungan Keluarga

Status ekonomi, sosial, kebiasaan dan suasana lingkungan keluarga berpengaruh terhadap keberhasilan belajar.

b. Lingkungan masyarakat

Peran masayarakat sangat mempengaruhi anak dalam belajar dan akan merubah tingkah laku anak dalam proses belajar.

c. Guru

Peran guru sangat berpengaruh dalam proses belajar anak. Cara mengajar sangat menentukan keberhasilan belajar sehingga guru perlu menjadi acuan selama proses pembelajaran berlangsung.

d. Media pembelajaran

Media pembelajaran juga mempengaruhi keberhasilan anak dalam belajar. Siswa cenderung berhasil apabila dibantu oleh media pembelajaran yang memadai.

\section{Metode}

Jenis penelitian yang digunakan dalam penelitian ini adalah penelitian deskriptif kualitatif. Penelitian ini di laksanakan di SMP Negeri Satap Amol pada semester genap tahun ajaran 2020/2021. Subjek penelitian ini adalah siswa kelas VIII A SMP Negeri Satap Amol yang berjumlah 18 siswa. Setelah melakukan tes terhadap 18 siswa tersebut, berdasarkan hasil pemeriksaan dipilihnya 3 siswa sebagai subjek penelitian untuk diwawancarai. Kriteria yang digunakan untuk penentuan subjek yaitu (1) siswa memiliki kemampuan untuk mengungkapkan pendapat dengan baik, sehingga wawancara dapat dilakukan dengan mudah. (2) siswa yang memperoleh nilai tinggi, siswa yang memperoleh nilai sedang dan siswa yang memperoleh nilai rendah yang dipilih dari hasil penyelesaian soal tes yang diberikan. Dalam penelitian ini teknik pengumpulan data yang digunakan adalah tes dan wawancara. Adapun instrumen yang digunakan dalam penelitian ini adalah: peneliti, lembar tes, pedoman wawancara dan dokumentasi. Metode yang digunakan untuk menganalisis data adalah analisis deskriptif kualitatif, yang dilakukan melalui tiga tahap yaitu: mereduksi data, pemaparan data dan menarik kesimpulan.

\section{Hasil Penelitian dan Pembahasan}




\section{Hasil Penelitian}

Penelitian ini dilakukan dalam beberapa tahap yaitu 1) memberikan tes. 2) Setelah memberikan tes kepada siswa, peneliti memeriksa lembar kerja siswa dalam menyelesaikan soal sistem persamaan linear dua variabel. 3) Setelah memeriksa lembar pekerjaan siswa, peneliti mengkonfirmasikan dengan guru mata pelajaran untuk melakukan wawancara. Pengumpulan data wawancara ini dilakukan dengan memilih 3 orang subjek yang telah dikategorikan untuk diwawancarai yaitu, kategori tinggi 1 orang siswa, kategori sedang 1 orang siswa dan kategori rendah 1 orang siswa untuk mengetahui kesulitan dan faktor penyebab siswa mengalami kesulitan dalam menyelesaikan soal tes. Berikut deskripsi hasil pekerjaan siswa dengan jenis-jenis kesalahan serta faktor-faktor penyebabnya:

\section{Deskripsi Kesulitan Dalam Mempelajari Konsep}

a. Deskripsi Hasil Tes dan Wawancara Siswa Yang Mendapatkan Nilai Tinggi S1 (FKB) Pada Soal Nomor 1

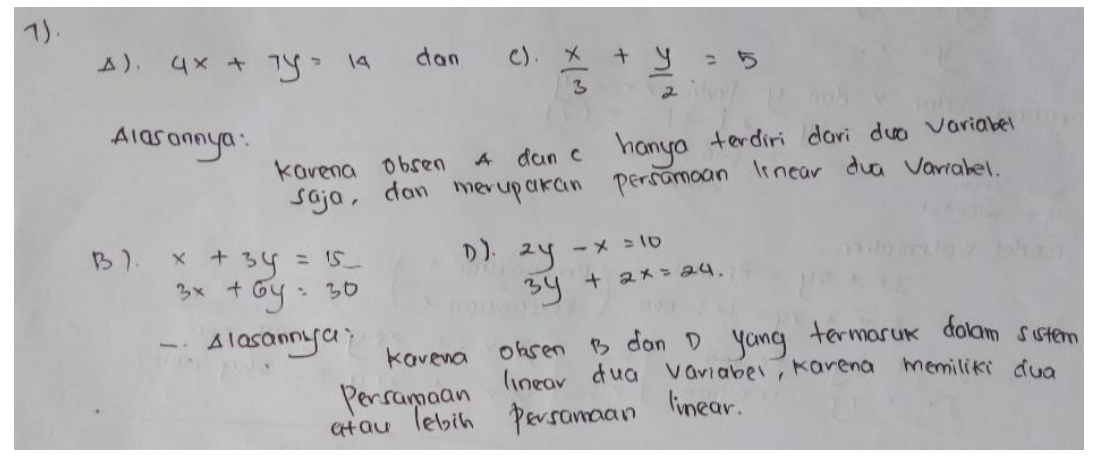

Gambar 1. Hasil Jawaban S1 Soal Nomor 1.

Dari hasil jawaban S1 mampu menentukan persamaan linear dua variabel dan sistem persamaan linear dua variabel dengan benar namun S1 tidak mampu memberikan alasan dengan tepat. S1 hanya menjelaskan persamaan linear dua variabel hanya terdiri dari dua variabel tanpa menyebutkan derajat pangkatnya dan sistem persamaan linear dua variabel memiliki dua atau lebih persamaan linear dua variabel.

b. Deskripsi Hasil Tes dan Wawancara Siswa Yang Mendapatkan Nilai Sedang S10 (KBB) Pada Soal Nomor 1 


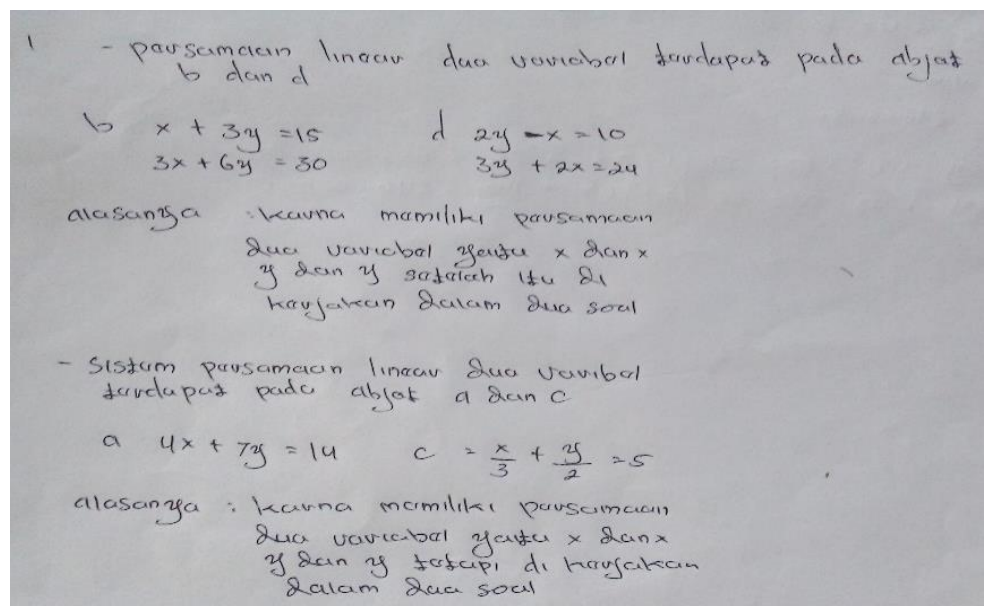

Gambar 2. Hasil Jawaban S10 Soal Nomor 1.

Dari hasil jawaban S10 salah memilih persamaan linear dua variabel dan sistem persamaan linear dua variabel. S10 memilih persamaan pada soal nomor 1b dan 1d merupakan bagian dari persamaan linear dua variabel sedangkan soal nomor 1a dan 1c merupakan bagian dari sistem persamaan linear dua variabel. S10 tidak mampu memberikan alasan yang tepat.

c. Deskripsi Hasil Tes dan Wawancara Siswa Yang Mendapatkan Nilai Rendah S18 (AS) Pada Soal Nomor 1

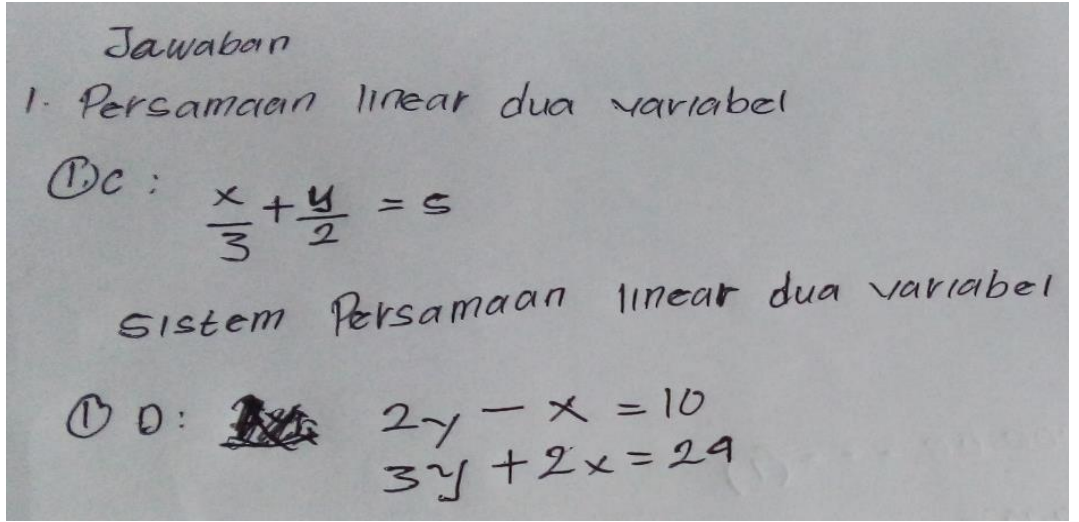

Gambar 3. Hasil Jawaban S13 Soal Nomor 1.

Dari hasil jawaban S18 sudah mampu memilih persamaan linear dua variabel dan sistem persamaan linear dua variabel dengan benar akan tetapi S18 tidak mampu memberikan alasan. Dari ke empat obsen yang diberikan, setiap persamaan S18 hanya memilih salah satu.

\section{Deskripsi Kesulitan Dalam Menerapkan Prinsip}

a. Deskripsi Hasil Tes dan Wawancara Siswa Yang Mendapatkan Nilai Tinggi S1 (FKB) Pada Soal Nomor 2 


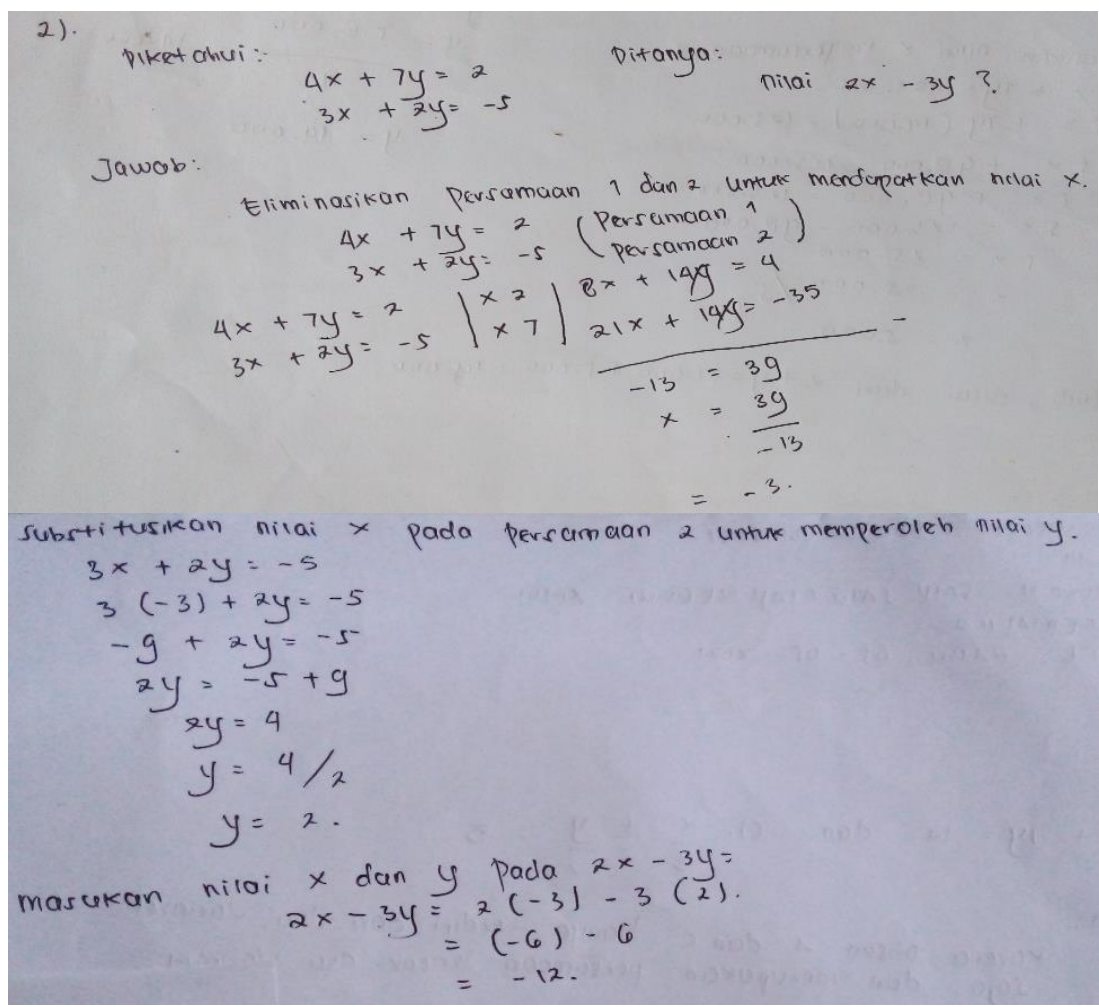

Gambar 4. Hasil Jawaban S1 Soal Nomor 2.

Dari hasil jawaban S1 sudah mengetahui cara menentukan nilai serta metode-metode yang ada pada sistem persamaan linear dua variabel, akan tetapi subjek kurang teliti dalam pengerjaannya sehingga S1 tidak menuliskan kesimpulannya.

b. Deskripsi Hasil Tes dan Wawancara Siswa Yang Mendapatkan Nilai Sedang S10 (KBB) Pada Soal Nomor 2

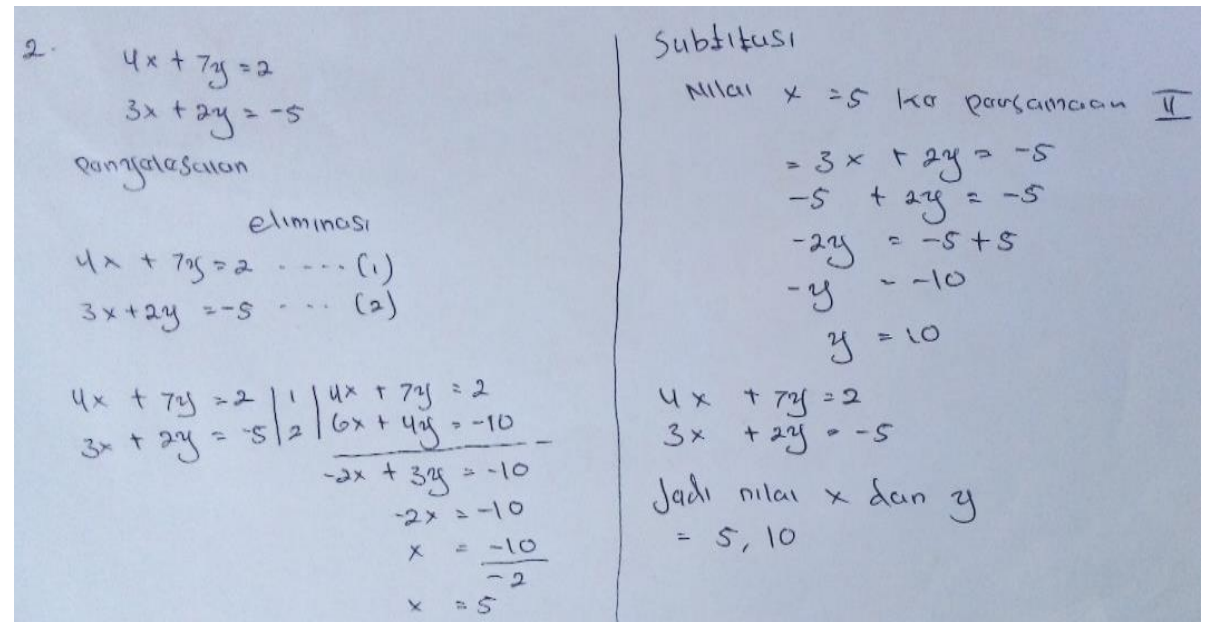

Gambar 5. Hasil Jawaban S10 Soal Nomor 2.

Dari hasil jawaban S10 sudah mengetahui metode-metode yang ada pada sistem persamaan linear dua variabel tetapi salah memilih koevisien yang digunakan untuk mengeliminasi variabel y dan kurang teliti dalam penjumlahan atau pengurangan pada pekerjaannya, dapat dilihat S10 menggunakan operasi pengurangan tapi terjadi kesalahan pada saat mengurangi. S10 mengoperasi pengurangan tanpa menyadari tanda jika $2-(-10)=12$ tetapi pada pekerjaan S5 menuliskan jika operasinya telah benar. 
c. Deskripsi Hasil Tes dan Wawancara Siswa Yang Mendapatkan Nilai Rendah S18 (AS) Pada Soal Nomor 2

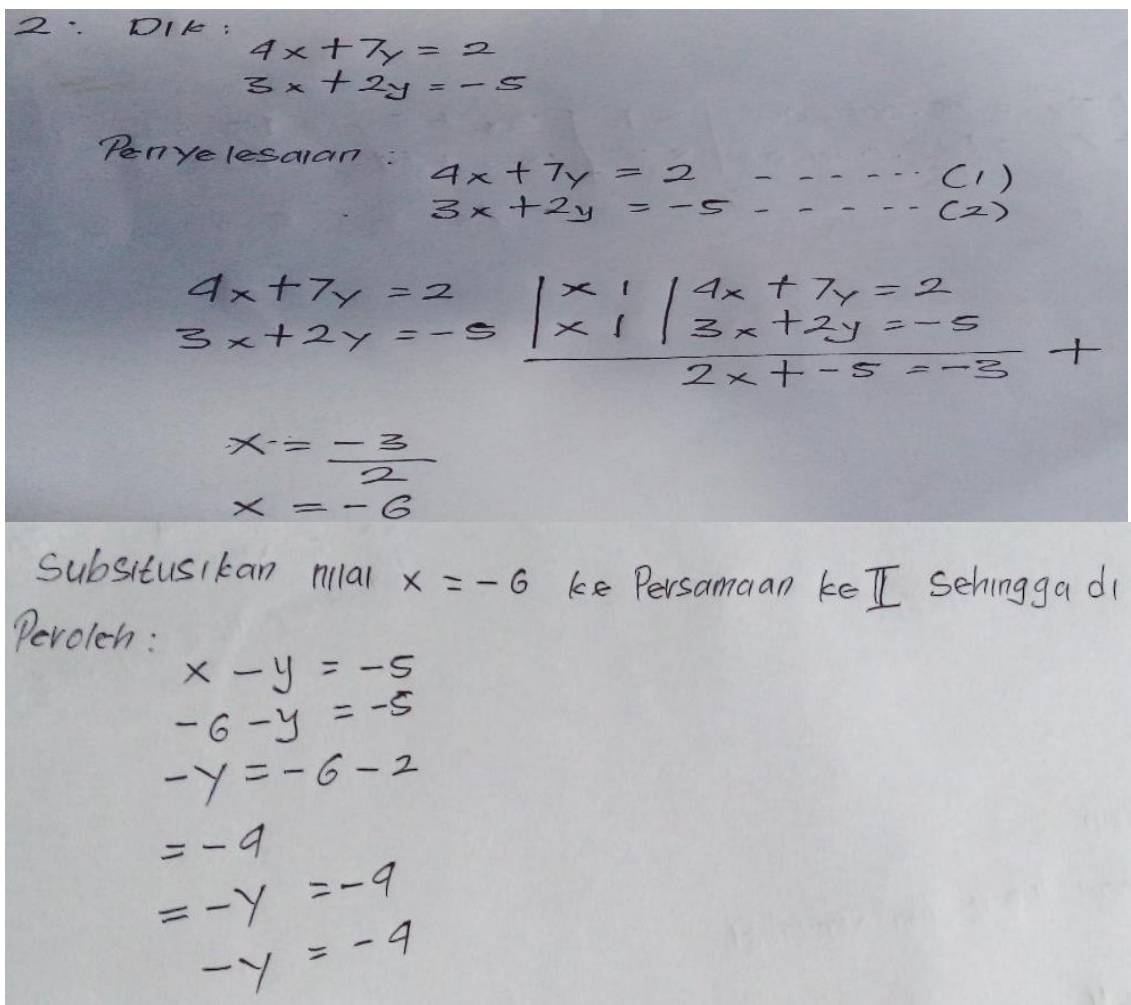

Gambar 6. Hasil Jawaban S18 Soal Nomor 2.

Dari hasil jawaban S18 sudah mengetahui metode-metode yang ada pada sistem persamaan linear dua variabel tetapi kurang teliti memilih koevisien yang digunakan untuk mengeliminasi variabel y sehingga salah memilih koefisien dan kurang teliti dalam penjumlahan atau pengurangan pada pekerjaannya. Dapat dilihat subjek menggunakan operasi penjumlahan tapi terjadi kesalahan pada saat menjumlahkan. Seharusnya pada perkerjaan tersebut dilakukan operasi pengurangan. Pada metode substitusi S18 kurang teliti dan juga keliru dalam mengerjakannya sehingga hasil pekerjaan siswa S18 pada soal nomor 2 salah.

\section{Deskripsi Kesulitan Dalam Menyelesaikan Masalah Verbal}

a. Deskripsi Hasil Tes dan Wawancara Siswa Yang Mendapatkan Nilai Tinggi S1 (FKB) Pada Soal Nomor 3 


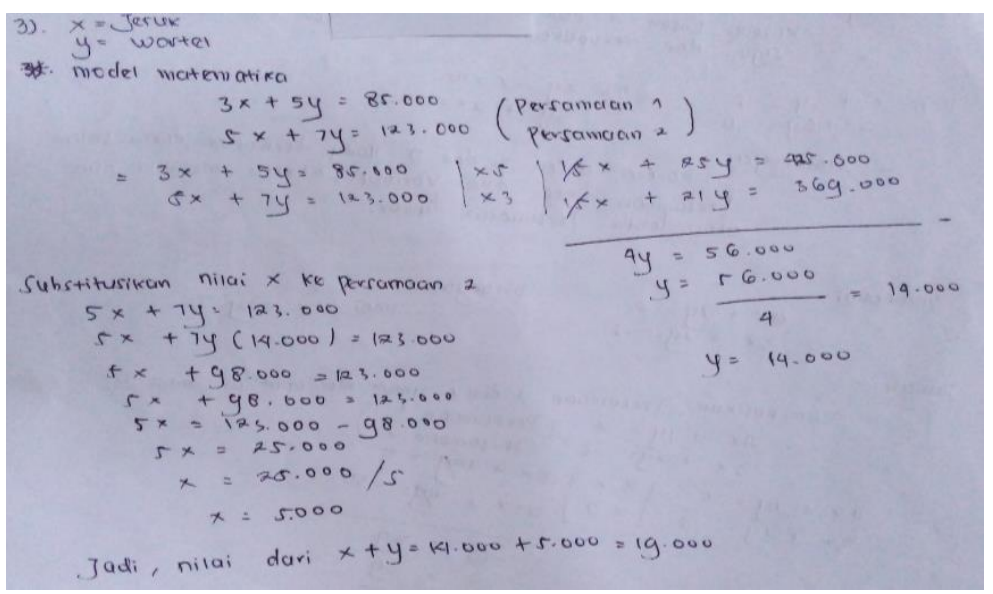

Gambar 7. Hasil Jawaban S1 Soal Nomor 3.

Dari hasil jawaban S1 sudah mampu merubah soal cerita menjadi model matematika dengan benar dan tepat tetapi S1 kurang teliti dalam pekerjaanya sehingga pada metode eliminasi variabel x yang dihilangkan untuk mendapatkan nilai y akan tetapi siswa S1 salah menuliskan $\mathrm{x}$ ke persamaan 2 dan tidak memahami maksud yang ditanyakan pada soal sehingga tidak menuliskan kesimpulan dengan baik.

b. Deskripsi Hasil Tes dan Wawancara Siswa Yang Mendapatkan Nilai Sedang S10 (KBB) Pada Soal Nomor 3

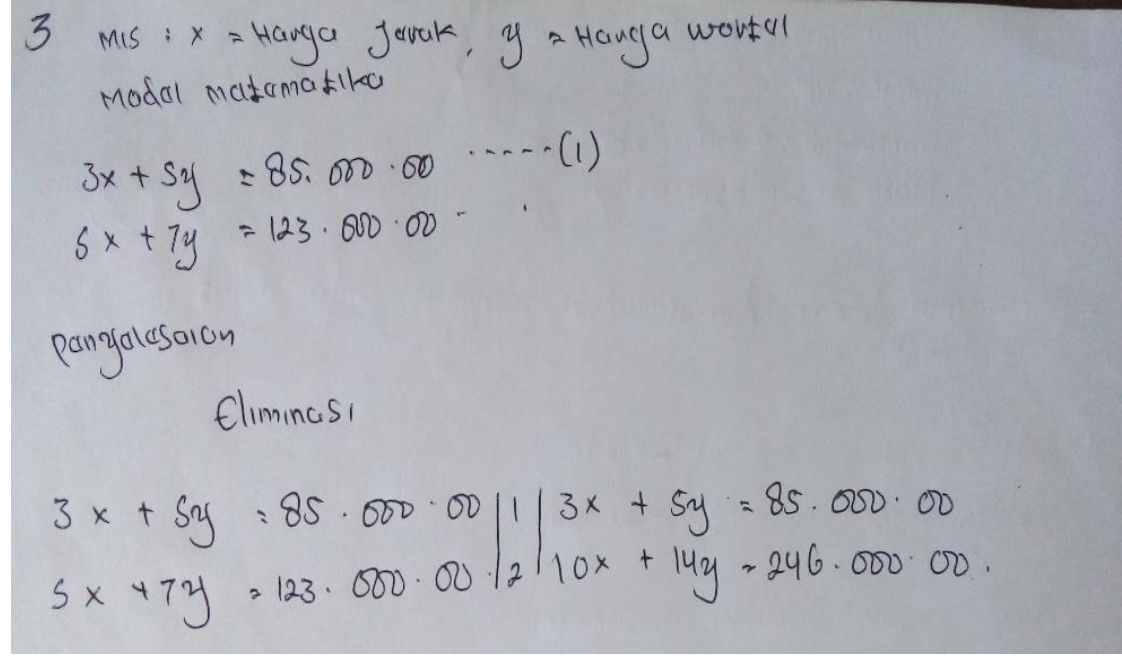

Gambar 8. Hasil Jawaban S10 Soal Nomor 3.

Dari hasil jawaban S10 belum paham maksud yang terdapat dalam soal sehingga belum memahami apa yang diketahui dan yang ditanyakan, tidak mampu mengerjakan metode eliminasi dan substitusi sehingga pekerjaan tidak dilanjutkan sampai akhir.

c. Deskripsi Hasil Tes dan Wawancara Siswa Yang Mendapatkan Nilai Rendah S18 (AS) Pada Soal Nomor 3 


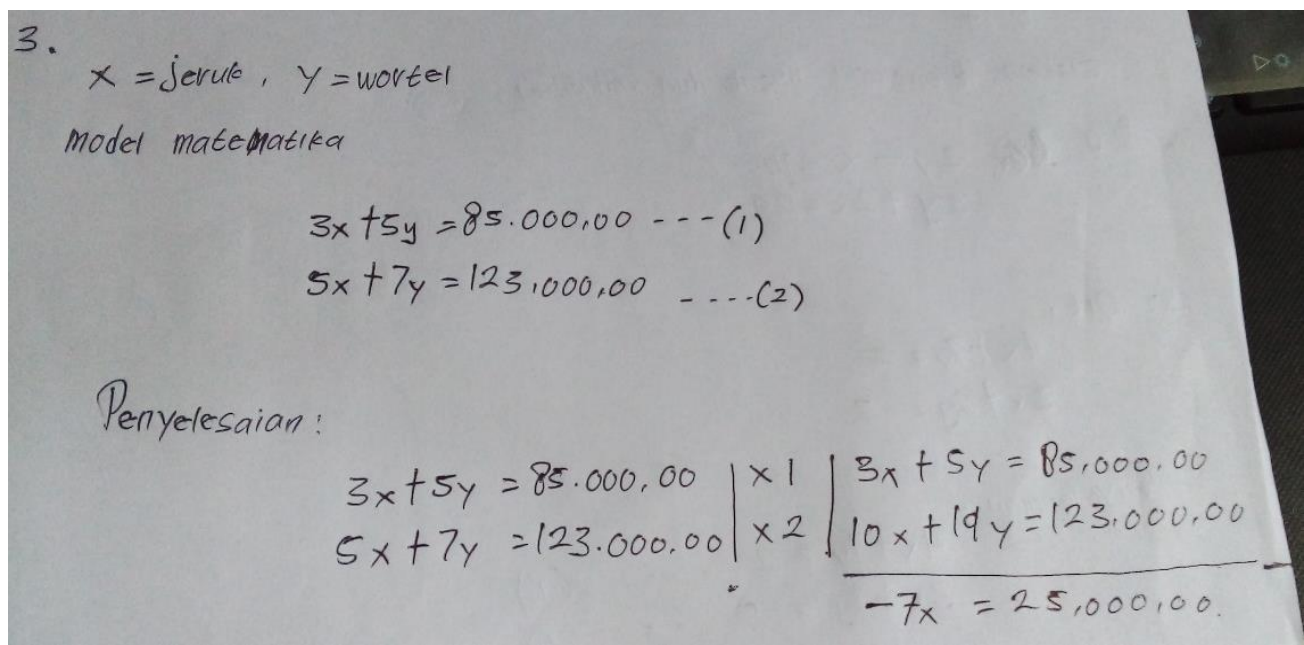

Gambar 9. Hasil Jawaban S18 Soal Nomor 3.

Dari hasil jawaban S18 belum paham maksud yang terdapat dalam soal sehingga belum memahami apa yang diketahui dan yang ditanyakan, tidak mampu mengerjakan metode eliminasi dan substitusi sehingga pekerjaan tidak dilanjutkan sampai akhir.

\section{Pembahasan}

Berdasarkan hasil penelitian, diketahui bahwa siswa kelas VIII SMP Negeri Satap Amol menunjukan bahwa siswa masih banyak yang mengalami kesulitan. Dari hasil tes dan wawancara peneliti memperhatikan tiga jenis indikator siswa mengalami kesulitan dalam menyelesaikan soal sistem persamaan linear dua variabel yaitu:

1. Kesulitan dalam mempelajari konsep

Kesulitan dalam mempelajari konsep dengan persentase 38,89\% yang dialami oleh subjek adalah dalam hal memahami konsep yang terdapat dalam matematika pada menentukan dan memberikan alasan dari persamaan linear dua variabel dan sistem persamaan linear dua variabel. Hal ini berarti konsep yang diajarkan guru tidak tertanam dengan baik sehingga siswa tidak terlalu paham dan lupa dengan yang pernah diajarkan. Sejalan dengan hasil analisis Sutriani Epriyanti (2016), kesulitan belajar konsep yang dialami oleh subjek adalah dalam hal memahami konsep yang terdapat dalam matematika pada memb edakan dan memberikan alasan dari contoh persamaan linear dua variabel dan sistem persamaan linear dua variabel.

Faktor penyebab subjek mengalami kesulitan dalam mempelajari konsep adalah subjek sudah lupa karena tidak belajar, catatan kurang lengkap, mengalami kekeliruan dan tidak bertanya pada guru ketika belum mengerti dan memahami karena siswa malu. Hal ini diperkuat oleh pendapat Amir dan Risnawati (2016) yang mengatakan bahwa salah satu faktor internal yang menyebabkan siswa kesulitan belajar adalah faktor intelegensi.

2. Kesulitan dalam menerapkan prinsip

Kesulitan dalam menerapkan prinsip dengan persentase 38,89\%. Kesulitan yang dialami subjek pada penerapan prinsip adalah subjek sudah mengetahui bagaimana cara menentukan nilai serta metode - metode yang ada pada sistem persamaan linear dua variabel tetapi mengalami 
kesulitan dalam menyamakan koefisien dari salah satu variabel sehingga subjek salah dalam menggunakan metode eliminasi dan keliru dalam operasi penjumlahan dan pengurangan sehingga hasil pekerjaannya salah. Sejalan dengan hasil analisis Sutriani Epriyanti (2016), subjek mengalami kesulitan prinsip saat melakukan operasi pengurangan angka yang terdapat pada pekerjaan subjek. Kesulitan belajar prinsip yang ditemukan adalah: subjek masih kurang teliti dan masih salah dalam melakukan operasi.

Faktor penyebab subjek mengalami kesulitan dalam menerapkan prinsip adalah siswa buru buru, kurang teliti dan keliru. Hal ini diperkuat oleh pendapat Amir dan Risnawati (2016) yang mengatakan bahwa salah satu internal yang menyebabkan siswa kesulitan belajar adalah faktor konsentrasi belajar, intelegensi dan kebiasaan belajar dalam mengikuti proses pembelajaran di sekolah.

3. Kesulitan dalam menyelesaikan masalah verbal

Kesulitan yang dialami subjek dalam menyelesaikan masalah verbal dengan persentase $50 \%$ adalah subjek tidak memahami maksud yang terdapat dalam soal. Subjek sudah mampu merubah soal cerita menjadi model matematika dengan benar dan tepat tetapi masih mengalami kesulitan. Kesulitan yang dialami siswa yaitu siswa masih salah dalam menyamakan koefisien yang digunakan untuk mengeliminasi salah satu variabel dan tidak mampu mengerjakan metode eliminasi dan substitusi sehingga pekerjaannya tidak dilanjutkan sampai akhir. Hal ini sejalan dengan hasil analisis Sutriani Epriyanti (2016), Kesulitan dalam memecahkan masalah verbal yaitu subjek kesulitan karena belum paham maksud yang terdapat dalam soal, sehingga subjek belum memahami apa yang diketahui dan yang ditanyakan.

Faktor penyebab subjek mengalami kesulitan dalam menyelesaikan masalah verbal adalah subjek kurang teliti dalam pekerjaanya, buru - buru, tidak melihat dengan baik suruhan pada soal, tidak menguasai materi, malu bertanya pada guru atau teman ketika tidak mengerti dan memahami, tidak mampu mengerjakan metode eliminasi dan substitusi sehingga pekerjaan tidak dilanjutkan sampai selesai dan tidak mengerti cara menyamakan koefisien untuk mengeliminasi salah satu variabel. Hal ini diperkuat oleh pendapat Amir dan Risnawati (2016) yang mengatakan bahwa salah satu faktor internal yang menyebabkan siswa kesulitan belajar adalah faktor konsentrasi belajar, intelegensi dan kebiasaan belajar dalam mengikuti proses pembelajaran di sekolah.

\section{Kesimpulan}

Berdasarkan hasil penelitian dan pembahasan dapat disimpulkan bahwa: 
1. Kesulitan yang dialami siswa dalam menyelesaikan soal sistem persamaan linear dua variabel yaitu: kesulitan dalam mempelajari konsep dengan persentase 38,89\%, kesulitan dalam menerapkan prinsip dengan persentase $38,89 \%$, kesulitan dalam menyelesaikan masalah verbal dengan persentase $50 \%$.

2. Faktor - faktor penyebab siswa mengalami kesulitan dalam menyelesaikan soal sistem persamaan linear dua variabel adalah: Penyebab siswa kesulitan dalam mempelajari konsep yaitu: siswa sudah lupa karena tidak belajar, catatan kurang lengkap, mengalami kekeliruan dan tidak bertanya pada guru ketika belum mengerti dan memahami karena siswa malu serta buru - buru dalam mengerjakan soal. Penyebab siswa kesulitan dalam menerapkan prinsip yaitu : siswa buru - buru, kurang teliti dan keliru. Penyebab siswa kesulitan dalam menyelesaikan masalah verbal yaitu : siswa kurang teliti dalam pekerjaanya, buru - buru, tidak melihat dengan baik suruhan pada soal, tidak menguasai materi, malu bertanya pada guru atau teman ketika tidak mengerti dan memahami, tidak mampu mengerjakan metode eliminasi dan substitusi sehingga pekerjaan tidak dilanjutkan sampai selesai dan tidak mengerti cara menyamakan koefisien untuk mengeliminasi salah satu variabel dan catatan siswa kurang lengkap.

\section{Rekomendasi}

Berdasarkan kesimpulan di atas, maka peneliti merekomendasikan kepada guru hendaknya mengarahkan siswa agar lebih teliti dalam mengerjakan soal, diharapkan banyak memberikan soal latihan untuk meningkatkan keterampilan dan ketelitian dalam mengerjakan soal pada materi sistem persamaan linear dua variabel, diharapkan memberikan konsep dasar seperti penjumlahan, pengurangan, perkalian dan pembangian kepada siswa dalam melakukan operasi hitung dan diharapkan melakukan pendampingan khusus bagi siswa - siswi yang mengalami kesulitan dalam mengerjakan soal sistem persamaan linear dua variabel.

\section{Referensi}

Abdurrahman M. (2012). Anak Berkesulitan Belajar: Teori, Diagnosis dan Remedianya. Jakarta: Rineka Cipta.

Abdurrahman, M. (2003). Pendidikan Bagi Anak Berkesulitan Belajar. Jakarta: Rineka Cipta.

Amir Z \& Risnawati. (2016). Psikologi Pembelajaran Matematika. Yogyakarta: Aswaja Pressindo.

Arafan A \& Khotimah RP. (2018). Analisis Kesulitan Menyelesaikan Soal Cerita Sistem Persamaan Linear Dua Variabel Siswa Kelas X Ssmk Harapan Kartasura (Doctoral dissertation, Universitas Muhammadiyah Surakarta).

Epriyanti S. (2016). Deskripsi Analisis Kesulitan Dalam Menyelesaikan Soal SPLDV Siswa SMA Kelas XI. Program Studi Pendidikan Matematika Fakultas Keguruan dan Ilmu Pendidikan Universitas Kristen Satya Wacana Jawa.

Febrini. (2017). Psikologi Pembelajaran Yogyakarta: Pustaka Pelajar. Jakarta. Rineka Cipta. 
Idris FH, Hamid I \& Ardiana A. (2016). Analisis Kesulitan Siswa Dalam Menyelesaikan Soal - Soal Penerapan Sistem Persamaan Linear Dua Variabel. Delta-Pi : Jurnal Matematika dan Pendidikan Matematika 3/2.

KBBI. (2020). Pengembangan Bahasa dan Perbukuan. Jakarta: Rineka Cipta.

Ruseffendi. (2006). Analisis Kesulitan Siswa Dalam Belajar Matematika Pada Materi Bentuk Pangkat, Akar dan Logaritma Kelas X. [Skripsi]. Gorontalo: Universitas Negeri Gorontalo.

Sasmita. (2019). Analisis Kesulitan Siswa Dalam Menyelesaikan Soal - Soal Sistem Persamaan Linear Dua Variabel Pada Kelas IX ${ }_{1}$ SMP Negeri I Bontumarannu. [Skripsi]. Makasar: Universitas Muhammadiyah Makasar.

Subini N d. (2012). Psikologi Pendidikan. Yogyakarta: Mentari Pustaka.

Sudijono A. (2009). Pengantar Statistic Pendidikan Edisi 1. Jakarta: Rajawali Pers.

Sudjana N. (2014). Penilaian Hasil Belajar Mengajar (Cetakan 18). Bandung: Remaja Rosdakarya.

Tursam Hakim. (2005). Kesulitan Belajar Pada anak. Jakarta: Aneka Cipta.

Wigati Tri Utami. (2012). Identifikasi Kesulitan Dalam Menyelesaikan Persoalan Matematika Yang berkaitan Dengan Pecahan Di Kelas VIII SMP N 3 Ngaglik Slamen Tahun Ajaran 2011/2012. [Skripsi]. Yogyakarta : Universitas Negeri Yogyakarta. 